\title{
Why was iron lost without significant isotope fractionation during the lateritic process in tropical environments?
}

\author{
Miao Li $\mathbf{i}^{\mathbf{a}}$, Yong-Sheng $\mathbf{H e}^{\mathbf{b}}$, Jin-Ting Kang ${ }^{\mathbf{a}}$, Xiao-Yong Yang ${ }^{\mathbf{a}}$, Zhi-Wei \\ $\mathbf{H e}^{\mathrm{a}}$, Hui-Min Yu ${ }^{\mathbf{a}}$, Fang Huang ${ }^{\mathrm{a}}$ *
}


To investigate the formation of laterites and Fe cycling during tropical weathering, this study presents Fe isotope and major trace-element compositions of a laterite profile obtained from an equatorial rainforest, Southern Philippines. The lateritic profile is $7 \mathrm{~m}$ deep from top soil to less-weathered peridotites. X-ray diffraction analyses reveal that the major Fe-bearing minerals are hematite and goethite. The profile shows a large variation in $\mathrm{Fe}_{2} \mathrm{O}_{3}$ concentrations (32.1-73.3 wt $\left.\%\right)$ and dramatic Fe loss based on $\tau_{\mathrm{Ti}}$, Fe factors $\left(\tau_{\mathrm{Ti}}\right.$, $\mathrm{Fe} \approx-50 \%$ to $-90 \%$ ) calculated from the open-system mass fraction transport function.

24 Notably, $\delta^{56} \mathrm{Fe}$ depicts a small range from $-0.03 \%$ in the peridotite to $+0.10 \%$ in the extremely weathered saprolites.

The small Fe isotopic fractionation and significant Fe loss provide important insights into Fe cycling during extreme weathering of peridotites in a tropical climate.

28 Variations in Fe content and $\delta^{56} \mathrm{Fe}$ can be modeled by a Rayleigh distillation process with 29 apparently small fractionation factors of ${ }^{56} \mathrm{Fe} /{ }^{54} \mathrm{Fe}$ between the saprolite and fluid $30\left(10^{3} \ln \alpha_{\text {saprolite-fluid }}\right)$ of 0.01 to 0.20 , much smaller than those experimentally determined for 31 reductive dissolution of goethite $\left(10^{3} \ln \alpha_{\text {goethite-Fe(II) }} \approx 1.2\right.$; Icopini et al., 2004) and hematite

$32\left(10^{3} \ln \alpha_{\text {hematite-Fe(II) }} \approx 1.3\right.$; Beard et al., 2003). These observations suggest that Fe should 33 have experienced a complete and in situ oxidation prior to $\mathrm{Fe}$ migration and $\mathrm{Fe}$ was 34 probably transferred in the form of colloidal substances. Fe transport over the history of the laterite formation and evolution may not have had a discernible effect on the $\mathrm{Fe}$ 36 isotopic composition of the ecosystem. 
37 Keywords: tropical weathering, laterite, iron isotope, Fe cycling.

\section{Introduction}

Laterites are oxidized Fe-rich soils covering one third of the continents and are drained by half of the continental rivers. They represent a key role in continental evolution, element cycling from the solid earth to the ocean, and development of terrestrial life (Tardy, 1997). It is therefore necessary to understand how they evolve in response to natural and anthropogenic processes. Iron is the fourth most abundant element in the continental crust and is also extremely abundant in laterites, as shown in their characteristic red color due to the large amount of $\mathrm{Fe}^{3+}$. Because $\mathrm{Fe}$ isotopes can be fractionated due to redox reaction during weathering and soil formation (Chapman et al., 2009; Fantle and DePaolo, 2004), Fe isotopic composition of soils can provide a useful tool to investigate laterite formation.

Understanding the behavior of $\mathrm{Fe}$ isotopes is important to evaluate transport of $\mathrm{Fe}$ during laterite formation and the impact on ecosystems. Previous studies on soils indicate that $\delta^{56} \mathrm{Fe}$ of bulk soils show a large range from $-0.62 \%$ to $+0.72 \%$ o (Emmanuel et al., 2005; Fantle and DePaolo, 2004; Fekiacova et al., 2013; Poitrasson et al., 2008;

Thompson et al., 2007; Wiederhold et al., 2007a; Wiederhold et al., 2007b). These pioneering studies have documented that notable Fe isotopic variation can occur due to reductive loss of $\mathrm{Fe}$ during weathering and soil formation (e.g., Bullen et al., 2001; Johnson et al., 2004; Wiederhold et al., 2006; Yesavage et al., 2012). Ligand-promoted dissolution, proton-promoted dissolution, or reductive Fe dissolution, have been proposed 
58 as the key process to control the Fe isotopic composition variation in soils (Emmanuel et

59 al., 2005; Fantle and DePaolo, 2004; Liermann et al., 2011; Wiederhold et al., 2006;

60 Wiederhold et al., 2007a). Yesavage et al. (2012) suggested that the notable Fe isotopic

61 fractionation in soils results from different dissolution and precipitation mechanisms.

62 They invoked two models to explain the iron isotopic variations: (i) the fractionation

63 occurs during dissolution process such as ligand-controlled dissolution or dissimilatory

64 iron reduction, both of which preferentially enrich light iron isotopes in solution; (ii) the

65 isotopic fractionation occurs during precipitation process rather than dissolution

66 (Yesavage et al., 2012), which can be explained using a fractionation factor between the

67 retained Fe precipitate and the mobile particles of 0.9987 (Skulan et al., 2002). There

68 were later iron isotope studies on tropical or subtropical laterite profiles (Liu et al., 2014;

69 Poitrasson et al., 2008). Liu et al. (2014) concerned laterites formed from basalt in

70 southern China, while Poitrasson et al. (2008) studied laterites formed from granodiorites

71 in Cameroon. Regardless of the different origin of laterites, they both demonstrate limited

$72 \delta^{56} \mathrm{Fe}$ variations $(<0.15 \%)$ of the whole profile with notable $\mathrm{Fe}$ loss during laterite

73 formation. Given that redox transport of Fe could significantly fractionate Fe isotopes, it

74 is not clear why Fe isotope fractionation is dramatically different in soils developed under

75 different climates. There is also a lack of understanding for the coupling of limited iron

76 isotope fractionation with dramatic iron loss. To better understand the $\mathrm{Fe}$ isotope

77 variations and Fe loss in laterite forming, we conduct a comprehensive Fe isotope study

78 for the laterites forming from weathering of peridotites under tropical climate. 
The lateritic profile in this study is from Surigao, South Philippines. Because the

80 climate is of an equatorial type with a mean annual rainfall of $\approx 3000 \mathrm{~mm}$ and a mean annual temperature of $27^{\circ} \mathrm{C}$, chemical weathering is significantly intensified and the laterite samples in this region have undergone extensive weathering. Therefore, laterites in Surigao, South Philippines, provide a good opportunity to study iron isotope fractionation and decipher iron cycling during extreme weathering processes. This is helpful for understanding how Fe is lost from the bedrocks to soil and water and how laterite forms via weathering of peridotites in tropical weather.

In this study, we report the Fe isotopic compositions, major- and trace-element contents of a typical lateritic profile developed from weathering of peridotites in Surigao, South Philippines. The purpose of this study is to understand the different response of $\mathrm{Fe}$ isotopes to weathering conditions and to investigate the cycling of Fe in the near-surface environment. We attribute the Fe lost with small Fe isotope variations in the laterite to a complete and in situ oxidation in the profile to the highly oxidized nature of the Surigao followed by migration, probably in the form of colloid substances, during laterite

94 formation under the tropical climate.

\section{Geology background and sample description}

The laterite in this study formed in a humid, tropical climate due to weathering of peridotites (Fig. 1). Peridotites are a common ultramafic igneous rock containing less than $45 \mathrm{wt} \%$ silica. They are very important because they are the dominant rock of the upper Earth's mantle. The mineral compositions of peridotites are mainly olivine, 
100 clinopyroxene, orthopyroxene, and Al-bearing phases that change with increasing depth 101 from plagioclase $(<30 \mathrm{~km})$ to spinel $(30-70 \mathrm{~km})$ and then to garnet $(>70 \mathrm{~km})$. The major 102 Fe-bearing minerals are olivine $\left((\mathrm{Mg}, \mathrm{Fe})_{2} \mathrm{SiO}_{4}\right)$ and pyroxene $\left(\left(\mathrm{Ca}, \mathrm{Na}, \mathrm{Fe}{ }^{\mathrm{II}}, \mathrm{Mg}\right)(\mathrm{Cr}, \mathrm{Al}\right.$, $\left.103 \mathrm{Fe}^{\mathrm{III}}, \mathrm{Mg}, \mathrm{Mn}, \mathrm{Ti}, \mathrm{V}\right) \mathrm{Si}_{2} \mathrm{O}_{6}$ ). Olivine is essentially free of $\mathrm{Fe}^{3+}$ compared with the other 104 mineral phases in peridotites (i.e., pyroxenes), while both ferrous and ferric irons can 105 exist in garnet, spinel, and pyroxene.

106 The weathering profile is located in Pili Country, Surigao, the capital city of Surigao 107 del Norte Province and $30 \mathrm{~km}$ west of Mainit Lake. This region has a mean annual 108 temperature of $27^{\circ} \mathrm{C}$. The highest maximum monthly temperature is $32-33^{\circ} \mathrm{C}$ during 109 August to September, and lowest maximum monthly temperature is $22-24^{\circ} \mathrm{C}$ during 110 January and February. Annual precipitation in Surigao is $\approx 3000 \mathrm{~mm}$ and most of the 111 precipitation occurs from November to March. Integrated geological and mineralogical 112 studies of the Surigao area can be found in Braxton et al. (2009).

113 The studied profile consists of peridotites at the bottom to extremely weathered 114 laterites toward the surface (Fig. 2). The topsoil in the upper $50 \mathrm{~cm}$ was not sampled to 115 avoid the disruption of vegetation activities onto iron isotopes. Beneath the topsoil, a set 116 of gravel layers has developed. Four samples (Pili-1 to Pili-4) were collected at intervals 117 of around $40 \mathrm{~cm}$ from the gravel layer. The gravels are hematite-rich nodules and the 118 X-ray diffraction (XRD) results reveal that this layer contains a higher proportion of clay 119 minerals than the other layers. Eleven samples (Pili-5 to Pili-15) were collected in the 120 fine laterite layer with a homogeneous red color from 200 to $590 \mathrm{~cm}$. The soil in this 
121 layer is fine in grain size. The soil color turns a little yellowish with the increase in depth,

122 but basically remains red. Four samples were collected from the section below $590 \mathrm{~cm}$,

123 where the soil becomes yellowish with less-weathered core stones with the texture of the

124 original parent rock. Green-yellow serpentinites $\left(\left(\mathrm{Mg}, \mathrm{Fe}^{\mathrm{II}}, \mathrm{Ni}\right)_{3} \mathrm{Si}_{2} \mathrm{O}_{5}(\mathrm{OH})_{4}\right)$ are visible

125 at the lower part of this layer, marking the weathering frontier of peridotites. At a higher

126 level in this layer, rock is soft with dark brownish colors mixed with shades of beige to

127 gray. A peridotite sample (Pili-21) was collected from $7 \mathrm{~m}$ below as a representative of

128 base rock (Fig. 2).

129 3. Analytical methods

130 Iron isotopic analyses were performed at the Metal Stable Isotope Laboratory of the

131 University of Science and Technology of China (USTC), Hefei, Anhui Province, China.

132 Procedures for sample dissolution, column chemistry, and instrumental analysis are

133 similar to those reported in previous studies (Huang et al., 2011). Briefly, samples were

134 dissolved in a mixture of concentrated $\mathrm{HF}-\mathrm{HNO}_{3}-\mathrm{HCl}$ in Savillex screw-top beakers.

135 Chemical separation of Fe was achieved by anion exchange chromatography with

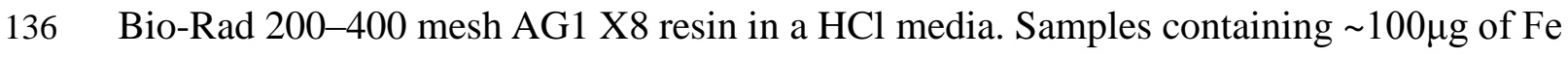

137 were loaded on the resin. Matrix elements were removed by $1.5 \mathrm{ml} 6 \mathrm{~N} \mathrm{HCl}$, and then $\mathrm{Fe}$

138 can be collected by $4 \mathrm{ml}$ of $0.5 \mathrm{~N} \mathrm{HCl}$ followed by $1 \mathrm{ml}$ of $8 \mathrm{~N} \mathrm{HNO}_{3}$ and $0.5 \mathrm{ml}$ of $\mathrm{H}_{2} \mathrm{O}$. Fe

139 yields were close to $100 \%$ and the procedure blanks were $\approx 17 \mathrm{ng}$, which is negligible

140 relative to the amount of Fe loaded to the column. At least two USGS rock standards

141 were measured during the isotope analyses of soils. 
142 Iron isotopic ratios were analyzed by the standard bracketing method using a

143 Neptune Plus MC-ICP-MS at the high resolution mode with mass resolution

$144 \mathrm{M} / \Delta \mathrm{M} \approx 8000$. Iron isotope data are reported in $\delta$-notation relative to IRMM-014:

$145 \delta^{\mathrm{X}} \mathrm{Fe}(\%)=\left[\left({ }^{\mathrm{X}} \mathrm{Fe} /{ }^{54} \mathrm{Fe}\right)_{\text {sample }} /\left({ }^{\mathrm{X}} \mathrm{Fe} /{ }^{54} \mathrm{Fe}\right)_{\text {IRMM }-014}-1\right] \times 1000$, where $\mathrm{X}=56$ or 57.

146 The long-term (12 months) average $\delta^{56} \mathrm{Fe}$ of the in-house standard (UIFe) was

$147 \quad 0.685 \pm 0.048 \%$ ( $2 \mathrm{SD}, n=663)$, and another in-house standard (GSB) was $0.719 \pm 0.048 \%$ o

148 (2SD, $n=391) . \delta^{56} \mathrm{Fe}$ of two international rock standards BHVO-2 and AGV-2 analyzed in

149 this study are $0.10 \pm 0.01$ and $0.09 \pm 0.03$ (Table 1 ), respectively, agreeing well with the

150 literature values (e.g., Craddock and Dauphas, 2011; Dauphas and Rouxel, 2006; He et al.,

151 2015). All samples including geostandards analyzed in this study define the mass

152 fractionation line in three-isotope space $\left(\delta^{57} \mathrm{Fe}\right.$ vs. $\left.\delta^{56} \mathrm{Fe}\right)$ with a slope of $1.494 \pm 0.137$

$153(1 \sigma)$, consistent with the theoretical kinetic and equilibrium fractionation values for Fe

154 isotopes (1.487 and 1.474, respectively) (Young et al., 2002).

155 Mineral compositions of the soils were measured on a BRUKER D8 ADVANCE

156 diffractometer in the Guangzhou Institute of Geochemistry, CAS. XRD patterns of the

157 samples were recorded between $3^{\circ}$ and $85^{\circ}(2 \theta)$ at a scanning speed of $4^{\circ} / \mathrm{min}$ with $\mathrm{Cu}$

$158 \mathrm{~K} \alpha$ radiation $(30 \mathrm{~mA}$ and $40 \mathrm{kV})$. The results are reported in Table 2.

159 Fresh laterite and peridotite samples were first powdered to $<200 \mu \mathrm{m}$ and then dried

160 at $\approx 100^{\circ} \mathrm{C}$ to remove absorbed water for elemental analysis. Major elements were

161 measured using a Rigaku ZSX100e X-ray fluorescence (XRF) spectrometer at ALS

162 Chemex Co Ltd. Trace elements were measured using a Perkin-Elmer Elan 6100 DRC 
163 ICP-MS at the CAS Key Laboratory of Crust-Mantle Materials and Environments,

164 USTC. Analytical procedures were described in Hou and Wang (2007). The

165 reproducibility was better than $5 \%$ for elements with concentrations $>10 \mathrm{ppm}$ and better

166 than $10 \%$ for those $<10$ ppm as monitored by USGS standard materials. For the

167 weathering laterite samples, most of the $\mathrm{Na}_{2} \mathrm{O}, \mathrm{CaO}$, and $\mathrm{K}_{2} \mathrm{O}$ are close to the detection

168 limits of XRF. Some conservative trace elements (such as $\mathrm{Nb}, \mathrm{U}$, and $\mathrm{Zr}$ ) also become

169 mobile during the extreme weathering process of peridotite so that the contents of some

170 trace elements are too low to be measured. Both major- and trace-element analytical

171 results are presented in Table 3.

172 4. Results

$173 \quad 4.1$ Elemental compositions

$174 \mathrm{Fe}_{2} \mathrm{O}_{3}(\mathrm{~T})(32.1-73.3 \mathrm{wt} \%)$ and $\mathrm{Al}_{2} \mathrm{O}_{3}(4.3-25.0 \mathrm{wt} \%)$ are obviously enriched in the

175 weathering products, which are around three to five fold higher than the peridotites. $\mathrm{SiO}_{2}$

176 concentrations in the top $2 \mathrm{~m}$ of the profile (6.3-24.9 wt\%) are lower than those in the

177 fresh peridotites, and they show a decreasing trend in the lower section from $3 \mathrm{~m}$ to $6 \mathrm{~m}$

178 (2.30 wt \% to $10.51 \mathrm{wt} \%)$ compared with the protolith (38 wt\%)(Fig. 3). MgO content of

179 the laterite $(0.43-5.13 \mathrm{wt} \%)$ is also dramatically lower than in the fresh peridotites $(\approx 40$

180 wt $\%)$.

181 Laterites formed in tropical or subtropical climate can produce mineral deposits. The

182 major mineral element Ni ranges from 600 to 4600 ppm, specifically enriched in the

183 bottom (layer IV) of the profile (Fig. 3). The abundances of most trace elements are 
184 higher in the lower section than in the upper section, whereas $\mathrm{Rb}, \mathrm{Zr}$, and $\mathrm{Nb}$ are enriched 185 or less depleted in the section above $2 \mathrm{~m}$ (Table 3 ).

186 In the tropics, the chemical index of alteration (CIA) and intensity of chemical

187 weathering (CIW) cannot be used to indicate the weathering degree because the

188 calculated fluid-mobile elements such as $\mathrm{K}, \mathrm{Ca}$, and $\mathrm{Na}$ can easily migrate out from the

189 weathered crust (Nesbitt and Wilson, 1992; Patino et al., 2005). As a result, these values,

190 like CIA and CIW, are almost $100 \%$ in this profile. The high concentrations of $\mathrm{Al}_{2} \mathrm{O}_{3}$ and

$191 \mathrm{Fe}_{2} \mathrm{O}_{3}$ (maximum values up to $24 \%$ and $73 \%$, respectively) suggest that the chemical

192 weathering intensity in the studied profile has been subjected to extreme weathering

193 (Nesbitt and Wilson, 1992).

$194 \quad 4.2 \mathrm{Fe}$ isotope compositions

195 Fe isotopic compositions of the peridotite and saprolites from the Surigao profile

196 are reported in Table 3. The peridotite sample has $\delta^{56} \mathrm{Fe}=-0.03 \%$, consistent with the

197 values of global peridotites (Beard et al., 2003; Dauphas et al., 2010; Weyer and

198 Schwieters, 2003; Zhao et al., 2012). The saprolites display a limited range of $\delta^{56} \mathrm{Fe}$ from

$199-0.03 \%$ to $+0.10 \%$ o $(n=20)$, slightly heavier than the protolith (Fig. 4a). In detail, the

200 gravel layer and homogeneous fine laterite layer show a limited variation of $\delta^{56} \mathrm{Fe}$

$201 \quad(-0.03 \%$ o to $+0.05 \%)$. Notably, a marked increase $(+0.10 \%)$ is found in the transition

202 horizon $(5.9 \mathrm{~m})$ between the fine laterite and the core stone laterite, corresponding to the

203 decreasing trend in Fe losses $\left(\tau_{\mathrm{Ti}}, \mathrm{Fe} \approx-75 \%\right.$ to $\left.-25 \%\right)$ (Fig. $\left.4 \mathrm{~b}\right)$.

204 5. Discussion 


\subsection{Element mobilization and distribution in the laterite}

The weathering of ultramafic rocks can significantly affect mobilization and

redistribution of elements, which plays an important role in the global mineral resource

economy. For example, the laterites developed in conditions such as those of the Surigao

can be used as Ni deposits (e.g., De Waal, 1970; Kühnel et al., 1978; Santos-Ynigo, 1964;

Zeissink, 1969). Thus, it is important to investigate the mechanism of element enrichment

based on the distribution of major and trace elements along the vertical profile.

$\mathrm{Mg}$ and $\mathrm{Fe}$ are enriched in the bottom (IV) and fine laterite layer (III) of the profile,

213 respectively (Fig. 3). The results of XRD analyses show that the core stone laterite layer

214 contains serpentine (Table 2). Thus, the Mg enrichment in the bottom of the laterite

215 profile is possibly due to existence of lizardites forming from hydrothermal alteration of

216 forsterites. Nahon et al. (1982a) suggested that the lizardite forms from a simple

217 hydrolysis process, in which fluid-mobile $\mathrm{Mg}$ is removed to the bottom of the profile

218 through the fissures and cracks in the layers. In contrast, the homogeneous fine laterite

219 layer (III) shows a sharp increase of iron content corresponding to a significant depletion

220 of $\mathrm{Mg}, \mathrm{Al}$, and $\mathrm{Si}$ (Fig. 3). Under the warm and oxidizing weathering conditions, Fe

221 should be completely transformed into ferric Fe, which is further precipitated with

222 hematite and goethite as the dominant Fe phases in the Surigao profile (Table 2).

223 However, $\mathrm{Si}, \mathrm{Mg}$, and mobile elements are released by the dissolution of silicates and

224 drained away from this layer during weathering.

225 To evaluate quantitatively the relative depletion or enrichment of an element during 
chemical weathering, we calculated the percentage changes of elemental ratios to $\mathrm{Ti}$

relative to parent rock, $\tau_{\mathrm{Ti}, \mathrm{j}}\left(\tau_{\mathrm{Ti}}, \mathrm{j}=100 \times\left[\left(C_{\mathrm{j}} / C_{\mathrm{Ti}}\right)_{\mathrm{s}} /\left(C_{\mathrm{j}} / C_{\mathrm{Ti}}\right)_{\mathrm{p}}-1\right]\right.$, where $C_{\mathrm{j}}$ and $C_{\mathrm{Ti}}$ represent

the concentration of elements $\mathrm{j}$ and Ti, respectively, and "s" and " $\mathrm{p}$ " refer to saprolite and

parent rock, Nesbitt and Markovics (1980)). Titanium is used as a conservative element

here because it is resistant to acidic environment in the basaltic weathering profiles (Hill

et al., 2000; Nesbitt and Markovics, 1980). Positive or negative $\tau_{\mathrm{Ti}, \mathrm{j}}$ values indicate

237 the most iron released from the parent rock was oxidized to $\mathrm{Fe}^{3+}$ with low solubility. So

238 Fe was enriched or less depleted compared to these mobile elements in laterites, even

239 though it was also significant lost according to the $\tau_{\mathrm{Ti}}$, Fe values.

240 Moreover, we observed that the highest Ni content occurs in the upper part of the

241 laterite with a core stone layer while the highest $\mathrm{Cr}$ content occurs in the bottom of the

242 homogeneous fine laterite layer (Table 3 and Fig. 3). It has been suggested that forsterites

243 are the Ni-bearing minerals, while enstatites are Cr-bearing minerals (Nahon et al.,

244 1982b). Talc and smectites are generated by weathering of forsterites and enstatites,

245 respectively. Therefore they are concentrated in Ni and $\mathrm{Cr}$ (Nahon et al., 1982a).

\subsection{Fe isotope fractionation along the laterite profile}


Despite the large Fe losses by $\sim 50 \%$ to $90 \%$ according to the $\tau_{\mathrm{Ti}}$, Fe factors (Fig. $4 \mathrm{~b}$ ),

248 their $\delta^{56} \mathrm{Fe}$ variations along the whole vertical profile are limited (0.13\%o) (Fig. 4a).

249 Consequently, our results are consistent with the previous studies that extreme weathering 250 and significant Fe lost may only induce limited Fe isotopic variation in laterites (Liu et al., 251 2014; Poitrasson et al., 2008). We have adopted a Rayleigh distillation model to simulate 252 the relationship between $\mathrm{Fe}$ loss and Fe isotope fractionation. Light Fe isotopes prefer 253 fluids to saprolites with an apparent $10^{3} \ln \alpha\left[\alpha=\left({ }^{56} \mathrm{Fe} /{ }^{54} \mathrm{Fe}\right)_{\text {saprolite }} /\left({ }^{56} \mathrm{Fe} /{ }^{54} \mathrm{Fe}\right)_{\text {fluid }}\right]$ varying 254 from 0.01 to 0.20 (Fig. 5). These values are much smaller than the fractionation factors 255 experimentally determined for reductive dissolution of goethite $\left(10^{3} \ln \alpha_{\text {goethite-Fe(II) }} \approx 1.2\right.$;

256 Icopini et al., 2004) and hematite $\left(10^{3} \ln \alpha_{\text {hematite-Fe( II) }} 1.3\right.$; Beard et al., 2003). Therefore, 257 the mechanism for Fe isotope fractionation and Fe loss in tropical weathering systems is 258 fundamentally different from the reductive dissolution of iron oxides. It is also possible 259 that proton-promoted dissolution does not cause measurable iron isotope fractionation 260 during the laterite formation process (Wiederhold et al., 2006). However, the $\mathrm{pH}$ of acid 261 required to dissolve $\mathrm{Fe}^{3+}$-bearing minerals is too low for the soils. For example, the 262 proton-promoted $(\mathrm{HCl})$ dissolution experiments of goethite in Wiederhold et al. (2006) 263 used $\mathrm{HCl}$ with $\mathrm{pH}$ of 0.3 , much lower than the typical laterite $\mathrm{pH}$ value $~ 4-6$ (Gidigasu, 264 2012). Thus, proton-promoted dissolution is not a major factor for $\mathrm{Fe}$ isotope 265 fractionation in the Surigao laterite.

266 It is difficult to evaluate how dissolution and leaching of Fe-bearing minerals 267 modulated Fe isotopic composition of the saprolites because most of the primary minerals 
reacted out. However, the consistent slopes of the Rayleigh distillation lines for the three

layers (Fig. 5) indicate that variations in iron isotopic compositions are still resolvable in tropical or subtropical laterites and among diverse weathering intensity horizons. Because

271 the $10^{3} \ln \alpha$ values are much smaller than the fractionation factors experimentally 272 determined for reductive dissolution of the Fe-bearing mineral hosts (e.g., goethite and 273 hematite), these values would not represent the effect of the reductive iron elemental 274 exchanges. In this view, this is clearly related to strong transformations of Fe-bearing 275 minerals during tropical weathering and laterite formation.

\subsection{The limited Fe isotopic variations in other soils}

The dramatic loss of $\mathrm{Fe}$ in the laterite profile and limited $\mathrm{Fe}$ isotope fractionation

provide important information for studying $\mathrm{Fe}$ transfer in soils and soil evolution. It allows us to evaluate the behavior of $\mathrm{Fe}$ in the near-surface environment during pedogenesis and to investigate evolution processes of soil (e.g., Fantle and DePaolo, 2004; have compiled the $\mathrm{Fe}$ isotope data showing limited fractionation in the profile

$283\left(\Delta^{56} \mathrm{Fe}_{\text {profile }}<0.15 \%\right)$ from a number of soil profiles published in the literature. The overall range for the bulk soils is $-0.21 \%$ to $+0.16 \%$ (Fig. 6 ). The soils can be divided into two groups on the basis of the common characteristics of formation environment. well-drained conditions with a dominantly vertical water transfer. The lack of Fe isotopic

288 fractionation in the profile could be due to limited transport of $\mathrm{Fe}^{3+}$ via water circulation 
289 because of the low solubility of $\mathrm{Fe}^{3+}$-bearing minerals such as goethite and hematite 290 (Poitrasson et al., 2008). Or alternatively, it could be due to that the Fe released from 291 mineral dissolution may in situ precipitate to form secondary minerals, as suggested by 292 Wiederhold et al. (2007a).

293 Group 2 soils are mainly haplic gleysols and the stagnic combisols with a similar 294 range of $\delta^{56} \mathrm{Fe}$ to group 1 . In contrast to the forming conditions of the group 1 soils, the 295 group 2 soils form in water-saturated and reduced conditions (Wiederhold et al., 2007b).

296 Because reductive Fe mobilization under anoxic state was inferred to occur in the studied 297 soils and the mobile fraction in soils in general has lighter Fe isotopic composition 298 (Brantley et al., 2004; Fantle and DePaolo, 2004; Thompson et al., 2007), the restricted 299 Fe isotopic variations may imply that the transport of Fe within the soil was spatially 300 limited. Therefore, most Fe could be transferred only at the scale of a few millimeters or 301 less so that significant Fe isotope variations cannot be observed in the reduced soils 302 (Wiederhold et al., 2007b).

303 To conclude, in the oxidized situations, the small Fe isotope fractionation in the 304 whole profile suggests that after iron released from the parent rock was oxidized to $\mathrm{Fe}^{3+}$, 305 the subsequent Fe mobility was limited due to the low solubility of the host minerals 306 (goethite and hematite). In reductive situations, limited Fe isotope fractionation suggests

307 that transport of aqueous $\mathrm{Fe}^{2+}$ species should be spatially limited (such as within 308 millimeter scales).

$309 \quad 5.4$ Implications for Fe cycling during lateritic weathering 
310 Mobilization of Fe in soils can be accompanied by notable Fe isotope fractionation

311 if $\mathrm{Fe}^{2+}$ is mobilized by water and organic acids or oxides are partially reduced (e.g.,

312 Emmanuel et al., 2005; Fantle and DePaolo, 2004) (Fig. 7a). In contrast, the restricted

$313 \delta^{56} \mathrm{Fe}$ variation and significant iron loss of the laterite profiles can be explained by entire

314 and in situ oxidation in tropical weather. In this case, the primary Fe-bearing minerals

315 decomposed and Fe was released from the minerals. Due to the high oxygen fugacity in

316 the tropical environment, a large amount of free oxygen enter from the atmosphere into

317 the soil through dry porous surfaces, cracks, and fissures of the profile so that the

318 oxidative process could be rapid (Yamaguchi et al., 2007) (Fig. 7b). Therefore, when $\mathrm{Fe}^{2+}$

319 encounters $\mathrm{O}_{2}$, it is completely oxidized to $\mathrm{Fe}^{3+}$ which further precipitates into

$320 \mathrm{Fe}^{3+}$-oxides and $\mathrm{Fe}^{3+}$-hydroxides.

321 As noted in Section 5.3, $\mathrm{Fe}^{3+}$ is not mobile in water to induce significant Fe loss.

322 Therefore, the most possible explanation for the negative $\tau_{\mathrm{Ti}}$, Fe could be associated with

323 ferric iron colloids. The positively charged iron colloidal materials can be vigorously

324 attached to negatively charged clay particles and they are leached together (Gidigasu,

325 2012; Maignien, 1966). Ferric iron can therefore be associated with certain substances

326 passing through soils. The variations of $\delta^{56} \mathrm{Fe}$ in the studied profile (from -0.03 to

$327+0.10 \%$ ) indicate that the iron isotope composition of ferric colloids is similar to the

328 continental crust $\left(\delta^{56} \mathrm{Fe}=0.07 \pm 0.02\right.$, Poitrasson, 2006). The results are different from

329 previous study showing that the organo-ferric colloids from subarctic and temperate area

330 are enriched in heavy Fe isotopes (Ilina et al., 2013). Ilina et al. (2013) also discovered a 
331 systematic difference of the correlation of $\delta^{57} \mathrm{Fe}$ with $\mathrm{Fe} / \mathrm{C}$ ratios between subarctic and 332 temperate water samples. Therefore, they attributed the nature of environments, like the

various soil/water situation and microbial activities, to control the iron isotope variations.

The Surigao profile formed under tropical climate with extreme weathering and Fe loss which is different with the cases of temperate and subarctic climate. Overall, the limited iron isotope variations in the laterites suggest that ferric Fe colloids are essential for iron migration during the extreme weathering process under (sub)tropical climate.

\section{Conclusions}

We report Fe isotopic compositions and element variations of a laterite profile developed from weathered peridotite from Surigao (Philippines) under a tropical climate.

The elemental geochemistry of laterite profile suggests that most elements, even the general conservative ones like $\mathrm{Fe}, \mathrm{Zr}$, and $\mathrm{Nb}$, become mobile during extreme weathering in tropical climate. The iron isotope results show that the lateritization process produced strong Fe loss $\left(\tau_{\mathrm{Ti}}, \mathrm{Fe} \approx-50 \%\right.$ to $\left.-90 \%\right)$ but limited iron isotope fractionation along the whole laterite profile $(0.13 \%)$. This observation has important implications for the geochemical cycling of Fe during laterite formation, suggesting that the studied profile should have experienced a complete and in situ oxidation before Fe migration. Finally, in order to lose $\mathrm{Fe}^{3+}$, Fe was probably transferred in the form of colloid substances.

\section{Acknowledgements}

This work is supported by the National Science Foundation of China (41325011, 41503001, 41571130052), the 111 Project, and the Fundamental Research Funds for the 
352 Central Universities. We are grateful to Ya Gao for providing the laterite samples from 353 the Surigao weathering profile. Yu-Han Qi, Tian-Tian Wang, Hong-Jie Wu, Juan Xu, 354 Xing-Chao Zhang, Ying-Zeng Gong, Zhen-Hui Hou, Shi-Chao An, and Yue Zhang are 355 thanked for help in laboratory. We are grateful to Chen Zhou, Fei Wu, Hong-Luo Zhang, 356 and Ya-Jun An for discussion. We also thank A.B. McBratney for editorial handling and 357 two anonymous referees for their constructive comments on the paper. 


\section{Figure captions}

360 Figure 1. A simplified geological map for South Philippines with sample location. Star represents sample locality.

362 Figure 2. Sketch section of the peridotite weathering profile in Surigao, South within the profile. Horizontal lines mark the boundaries of each layer. The boundaries between these horizons are gradual. Sample numbers are marked at their sampling positions in the profile.

Figure 3. The compositional variations of $\mathrm{Fe}, \mathrm{Al}, \mathrm{Mg}, \mathrm{Si}, \mathrm{Cr}$, and $\mathrm{Ni}$ relative to the protolith along the weathering profile. The layer designations are: I, topsoil; II, gravel layer; III homogeneous fine laterite layer; IV, laterite with core stone; and V, peridotite.

Figure 4. (a) $\delta^{56} \mathrm{Fe}$ and (b) $\tau_{\mathrm{Ti}}$, Fe as a function of depth in the weathering profile. Error bars represent 2 standard deviation. The layer I, I, III, IV, and V are similar to Figure 3.

Figure 5. Correlation of $\delta^{56} \mathrm{Fe}$ with iron concentration normalized to titanium. Solid lines depict Fe removal via Rayleigh distillation with different fractionation factor $10^{3} \ln \alpha$ $\left[\alpha=\left({ }^{56} \mathrm{Fe} /{ }^{54} \mathrm{Fe}\right)_{\text {saprolite }} /\left({ }^{56} \mathrm{Fe} /{ }^{54} \mathrm{Fe}\right)_{\text {fluid }}\right] . \quad \delta^{56} \mathrm{Fe}_{\text {saprolite }}=\left(\delta^{56} \mathrm{Fe}_{\text {peridotite }}+1000\right) \mathrm{f}^{(\alpha-1)}-1000$, where $f$ is the fraction of $F e$ remaining in the rock as calculated from $\mathrm{Fe}_{\text {saprolite }} / \mathrm{Fe}_{\text {peridotite. }}$ Star represents peridotite; triangles represent samples at gravel layer; open circles represent samples at homogeneous fine laterite; and diamonds are samples at laterite with core stone. Vertical dashed lines indicate the relative percentage of sample Fe loss.

Figure 6. Range of $\delta^{56} \mathrm{Fe}$ in bulk soil samples from worldwide. Compared to other soils previously studied, twenty laterite samples from Surigao, Philippines show a small range of Fe isotope variations similar to the continental crust mean value (Poitrasson, 2006). Soils in the literature are from Cameroon (P-2008. Poitrasson et al., 2008), 

(W-2007a. Wiederhold et al., 2007a), Switzerland (W-2007b. Wiederhold et al., 2007b) and Israel (E-2005. Emmanuel et al., 2005). Vertical dashed lines represent $\delta^{56} \mathrm{Fe}$ of the continent crust (Poitrasson, 2006).

390 Figure 7. A schematic model showing laterite formation process. (a) Under reduced situation, removal of Fe with low $\delta^{56} \mathrm{Fe}$ through mobilization by water, organic acids and/or $\mathrm{Fe}^{3+}$-reducing bacteria could produce a residue with heavy $\delta^{56} \mathrm{Fe}$. (b) Under the oxidized situation, infiltrating atmospheric $\mathrm{O}_{2}$ produces $\mathrm{Fe}^{3+}$-oxides and/or Fe without significant fractionation of Fe isotopes. 
397 Table 1. Fe isotopic compositions of USGS rock standards analyzed in this study.

398

\begin{tabular}{cccccccccc}
\hline Sample type & Name & $\delta^{56} \mathrm{Fe}$ & $2 \mathrm{SD}$ & $\mathrm{n}$ & $\delta^{57} \mathrm{Fe}$ & $2 \mathrm{SD}$ & $\mathrm{n}$ & $\delta^{56} \mathrm{Fe}^{*}$ & $\delta^{57} \mathrm{Fe}^{*}$ \\
\hline Basalt, USA & BHVO-2 & 0.10 & 0.01 & 4 & 0.21 & 0.07 & 4 & $0.11 \pm 0.01$ & $0.17 \pm 0.02$ \\
Andesite, USA & AGV-2 & 0.09 & 0.03 & 4 & 0.11 & 0.08 & 4 & $0.11 \pm 0.01$ & $0.15 \pm 0.02$
\end{tabular}

399

$400 \mathrm{n}$, repeat measurements of a sample solution. *, recommended value from Craddock and Dauphas 401 (2011).

402 
403 Table 2. Mineral proportion (wt\%) of the laterite profile.

404

\begin{tabular}{ccccc}
\hline & Goethite & Hematite & Illite & Serpentine \\
\hline Pili1 & 63.7 & & 36.3 & \\
Pili2 & 44.3 & & 55.7 & \\
Pili3 & 65.7 & 14.1 & 20.2 & \\
Pili4 & 65 & 24.4 & 10.7 & \\
Pili5 & 72.9 & 27.1 & & \\
Pili6 & 47.8 & 52.2 & & \\
Pili7 & 40.4 & 59.6 & & \\
Pili8 & 42.7 & 57.3 & & \\
Pili9 & 51.7 & 48.3 & & \\
Pili10 & 47.8 & 52.2 & & \\
Pili11 & 63.4 & 36.6 & & \\
Pili12 & 35 & 65 & & \\
Pili13 & 35.9 & 64.1 & & \\
Pili14 & 61 & 39 & & \\
Pili15 & 43.8 & 56.2 & & \\
Pili16 & 42.7 & 57.3 & & \\
Pili17 & 23.4 & 76.6 & & \\
Pili18 & 25.8 & 74.2 & & \\
Pili19 & & 13.7 & & \\
Pili20 & & 14.6 & & \\
Pili21 & & 14.4 & & \\
\hline
\end{tabular}


Table 3. Major-trace element concentrations and $\delta^{56} \mathrm{Fe}$ of laterites and peridotite from Surigao, Philippines

\begin{tabular}{|c|c|c|c|c|c|c|c|c|c|c|c|c|}
\hline Sample & $\operatorname{Depth}(\mathrm{m})$ & $\begin{array}{l}\mathrm{Fe}_{2} \mathrm{O}_{3} \\
(\mathrm{wt} \%)\end{array}$ & $\begin{array}{c}\mathrm{MgO} \\
(\mathrm{wt} \%)\end{array}$ & $\begin{array}{l}\mathrm{Al}_{2} \mathrm{O}_{3} \\
(\mathrm{wt} \%)\end{array}$ & $\begin{array}{l}\mathrm{SiO}_{2} \\
(\mathrm{wt} \%)\end{array}$ & $\mathrm{Ni}(\mathrm{ppm})$ & $\mathrm{Cr}(\mathrm{ppm})$ & $\mathrm{Rb}(\mathrm{ppm})$ & $\mathrm{Sr}(\mathrm{ppm})$ & $\mathrm{Ba}(\mathrm{ppm})$ & $\mathrm{Zr}(\mathrm{ppm})$ & $\mathrm{Nb}(\mathrm{ppm})$ \\
\hline Pili1 & 0.6 & 32.14 & 0.46 & 22.24 & 22.92 & 642 & 1935 & 0.38 & 8.48 & 25.71 & 27.27 & 1.14 \\
\hline Pili2 & 1.0 & 27.86 & 0.45 & 24.99 & 24.90 & 613 & 1514 & 0.45 & 6.46 & 52.17 & 32.64 & 1.25 \\
\hline Pili3 & 1.4 & 33.31 & 0.48 & 22.72 & 21.92 & 741 & 2410 & 0.42 & 9.17 & 37.63 & 27.22 & 1.16 \\
\hline Pili4 & 2.0 & 60.05 & 0.39 & 13.27 & 6.32 & 1552 & 2447 & 0.19 & 0.81 & 9.27 & 12.12 & 0.61 \\
\hline Pili5 & 2.6 & 70.47 & 0.46 & 8.17 & 2.42 & 2225 & 3395 & 0.13 & 0.36 & 7.46 & 5.54 & 0.29 \\
\hline \multicolumn{13}{|l|}{ Pili5 } \\
\hline Pili6 & 3.4 & 71.41 & 0.43 & 8.26 & 2.30 & 2609 & 3198 & 0.12 & 0.34 & 2.89 & 5.15 & 0.28 \\
\hline Pili7 & 3.8 & 70.69 & 0.64 & 8.63 & 3.18 & 2762 & 3092 & 0.18 & 0.40 & 5.69 & 5.31 & 0.28 \\
\hline Pili8 & 4.2 & 69.24 & 0.65 & 9.03 & 3.72 & 2429 & 4327 & 0.18 & 0.44 & 4.44 & 4.35 & 0.22 \\
\hline Pili9 & 4.6 & 68.10 & 0.72 & 9.18 & 4.26 & 2617 & 4457 & 0.20 & 0.42 & 7.99 & 4.59 & 0.20 \\
\hline Pili10 & 4.8 & 65.90 & 0.73 & 9.66 & 5.81 & 2618 & 6068 & 0.23 & 0.48 & 8.44 & 5.16 & 0.20 \\
\hline Pili11 & 5.1 & 63.92 & 0.54 & 9.08 & 7.03 & 2302 & 3749 & 0.24 & 0.47 & 2.88 & 3.92 & 0.18 \\
\hline Pili12 & 5.3 & 72.69 & 0.78 & 6.33 & 3.89 & 3271 & 5181 & 0.16 & 0.47 & 4.28 & 2.12 & 0.10 \\
\hline Pili13 & 5.4 & 73.28 & 0.86 & 6.13 & 4.34 & 2905 & 4545 & 0.13 & 0.39 & 2.70 & 1.55 & 0.07 \\
\hline Pili14 & 5.5 & 58.88 & 0.92 & 9.13 & 10.51 & 2425 & 3531 & 0.22 & 1.03 & 6.61 & 4.18 & 0.18 \\
\hline Pili15 & 5.6 & 67.43 & 1.00 & 7.46 & 7.16 & 3107 & 5452 & 0.17 & 0.61 & 3.46 & 2.12 & 0.08 \\
\hline Pili16 & 5.9 & 64.16 & 1.37 & 7.81 & 8.79 & 2816 & 5525 & 0.12 & 0.73 & 6.68 & 0.67 & 0.03 \\
\hline \multicolumn{13}{|l|}{ Pili16* } \\
\hline Pili17 & 6.0 & 53.86 & 3.35 & 4.30 & 19.17 & 4569 & 4153 & 0.14 & 1.39 & 13.86 & 0.51 & 0.01 \\
\hline Pili18 & 6.2 & 49.83 & 5.13 & 4.40 & 20.82 & 4671 & 2747 & 0.13 & 1.94 & 15.23 & 0.21 & 0.01 \\
\hline \multicolumn{13}{|l|}{ Pili18* } \\
\hline Pili19 & 6.4 & 13.10 & 29.14 & 1.08 & 38.41 & 2825 & 1027 & 0.07 & 0.91 & 5.15 & 0.17 & 0.00 \\
\hline Pili20 & 6.8 & 13.23 & 28.84 & 0.89 & 38.72 & 3804 & 998 & 0.07 & 1.00 & 4.71 & 0.04 & 0.00 \\
\hline Pili21 & 7.2 & 12.88 & 29.14 & 0.61 & 38.97 & 3130 & 1120 & 0.06 & 0.64 & 3.89 & 0.10 & 0.00 \\
\hline
\end{tabular}

Sample Pili21 is peridotite and other samples are laterites. $\tau_{\mathrm{Ti}, j}=100 \times\left[\left(\mathrm{C}_{\mathrm{j}} / \mathrm{C}_{\mathrm{Ti}}\right)_{\text {saprolite }} /\left(\mathrm{C}_{\mathrm{j}} / \mathrm{C}_{\mathrm{Ti}}\right)_{\text {protolith }}-1\right]$, where j refers to mobile element. $\mathrm{Fe}_{2} \mathrm{O}_{3}(\mathrm{~T})$ is total Fe.* refers to replicate that is repeated sample dissolution, column chemistry and measurement of isotope ratio. a, 2SD was calculated based on repeated measurements by MC-ICP-MS for three times. 
Table 3 (continued).

\begin{tabular}{ccccccccc}
\hline Sample & Depth(m) & $\mathrm{Ti}(\mathrm{ppm})$ & $\tau_{\mathrm{Ti}, \mathrm{Fe}}(\%)$ & $\mathrm{SiO}_{2} / \mathrm{Al}_{2} \mathrm{O}_{3}$ & $\delta^{56} \mathrm{Fe}$ & $2 \mathrm{SD}^{\mathrm{a}}$ & $\delta^{57} \mathrm{Fe}$ & $2 \mathrm{SD}^{\mathrm{a}}$ \\
\hline Pili1 & 0.6 & 1.72 & -97.8 & 1.0 & 0.02 & 0.01 & 0.02 & 0.03 \\
Pili2 & 1.0 & 1.92 & -98.3 & 1.0 & 0.02 & 0.02 & 0.03 & 0.03 \\
Pili3 & 1.4 & 1.64 & -97.6 & 1.0 & 0.01 & 0.04 & 0.03 & 0.01 \\
Pili4 & 2.0 & 0.82 & -91.4 & 0.5 & -0.01 & 0.02 & 0.02 & 0.01 \\
Pili5 & 2.6 & 0.42 & -80.1 & 0.3 & 0.00 & 0.03 & 0.01 & 0.04 \\
Pili5 & & & & & 0.03 & 0.02 & 0.07 & 0.03 \\
Pili6 & 3.4 & 0.42 & -80.2 & 0.3 & 0.00 & 0.03 & 0.04 & 0.10 \\
Pili7 & 3.8 & 0.44 & -81.1 & 0.4 & -0.03 & 0.02 & -0.05 & 0.06 \\
Pili8 & 4.2 & 0.40 & -79.6 & 0.4 & 0.03 & 0.03 & 0.02 & 0.04 \\
Pili9 & 4.6 & 0.40 & -79.7 & 0.5 & 0.01 & 0.03 & 0.03 & 0.03 \\
Pili10 & 4.8 & 0.42 & -81.3 & 0.6 & 0.02 & 0.01 & 0.04 & 0.03 \\
Pili11 & 5.1 & 0.31 & -75.4 & 0.8 & 0.00 & 0.05 & 0.04 & 0.08 \\
Pili12 & 5.3 & 0.20 & -57.3 & 0.6 & -0.01 & 0.03 & 0.01 & 0.05 \\
Pili13 & 5.4 & 0.17 & -49.7 & 0.7 & 0.02 & 0.04 & 0.02 & 0.05 \\
Pili14 & 5.5 & 0.30 & -76.7 & 1.2 & 0.05 & 0.04 & 0.04 & 0.09 \\
Pili15 & 5.6 & 0.19 & -58.0 & 1.0 & 0.05 & 0.03 & 0.08 & 0.10 \\
Pili16 & 5.9 & 0.16 & -51.3 & 1.1 & 0.10 & 0.04 & 0.16 & 0.02 \\
Pili16 & & & & & 0.09 & 0.04 & 0.10 & 0.07 \\
Pili17 & 6.0 & 0.08 & -24.2 & 4.5 & 0.02 & 0.03 & 0.01 & 0.02 \\
Pili18 & 6.2 & 0.06 & -2.7 & 4.7 & -0.02 & 0.04 & -0.02 & 0.10 \\
Pili18* & & & & & -0.01 & 0.04 & 0.00 & 0.05 \\
Pili19 & 6.4 & 0.02 & -38.0 & 35.6 & 0.05 & 0.03 & 0.12 & 0.06 \\
Pili20 & 6.8 & 0.01 & 15.6 & 43.5 & 0.00 & 0.04 & -0.01 & 0.05 \\
Pili21 & 7.2 & 0.02 & 0 & 63.9 & -0.03 & 0.02 & -0.05 & 0.05 \\
\hline & & & & & & & &
\end{tabular}




\section{References}

Beard, B.L. et al., 2003. Application of Fe isotopes to tracing the geochemical and biological cycling of Fe. Chemical Geology, 195(1): $87-117$.

Brantley, S.L. et al., 2004. Fe isotopic fractionation during mineral dissolution with and without bacteria. Geochimica et Cosmochimica Acta, 68(15): 3189-3204.

Braxton, D.P., Cooke, D.R., Ignacio, A.M., Rye, R.O., Waters, P.J., 2009. Ultra-deep oxidation and exotic copper formation at the late Pliocene Boyongan and Bayugo porphyry copper-gold deposits, Surigao, Philippines: geology, mineralogy, paleoaltimetry, and their implications for geologic, physiographic, and tectonic controls. Economic Geology, 104(3): 333-349.

Chapman, J.B., Weiss, D.J., Shan, Y., Lemburger, M., 2009. Iron isotope fractionation during leaching of granite and basalt by hydrochloric and oxalic acids. Geochimica et Cosmochimica Acta, 73(5): 1312-1324.

Craddock, P.R., Dauphas, N., 2011. Iron isotopic compositions of geological reference materials and chondrites. Geostandards and Geoanalytical Research, 35(1): 101-123.

Dauphas, N., Rouxel, O., 2006. Mass spectrometry and natural variations of iron isotopes. Mass Spectrometry Reviews, 25(4): 515-550.

Dauphas, N., Teng, F.-Z., Arndt, N.T., 2010. Magnesium and iron isotopes in 2.7 Ga Alexo komatiites: mantle signatures, no evidence for Soret diffusion, and identification of diffusive transport in zoned olivine. Geochimica et Cosmochimica Acta, 74(11): 3274-3291.

De Waal, S., 1970. Nickel minerals from Barberton, South Africa: III. Willemseite, a nickel-rich talc. American Mineralogist, 55(1-2): 31-42.

Emmanuel, S., Erel, Y., Matthews, A., Teutsch, N., 2005. A preliminary mixing model for Fe isotopes in soils. Chemical geology, 222(1): 23-34.

Fantle, M.S., DePaolo, D.J., 2004. Iron isotopic fractionation during continental weathering. Earth and Planetary Science Letters, 228(3): 547-562.

Fekiacova, Z., Pichat, S., Cornu, S., Balesdent, J., 2013. Inferences from the vertical distribution of Fe isotopic compositions on pedogenetic processes in soils. Geoderma, 209: 110-118.

Gidigasu, M., 2012. Laterite soil engineering: pedogenesis and engineering principles, 9. Elsevier.

He, Y. et al., 2015. High - Precision Iron Isotope Analysis of Geological Reference Materials by High - Resolution MC - ICP - MS. Geostandards and Geoanalytical Research, 39(3): 341-356.

Hill, I., Worden, R., Meighan, I., 2000. Yttrium: The immobility-mobility transition during basaltic weathering. Geology, 28(10): 923-926.

Hou, Z.-h., Wang, C.-x., 2007. Determination of 35 trace elements in geological samples by inductively coupled plasma mass spectrometry. Journal of University of Science and Technology of China, 37: 940-944.

Huang, F., Zhang, Z., Lundstrom, C.C., Zhi, X., 2011. Iron and magnesium isotopic compositions of peridotite xenoliths from Eastern China. Geochimica et Cosmochimica Acta, 75(12): 3318-3334.

Icopini, G., Anbar, A., Ruebush, S., Tien, M., Brantley, S., 2004. Iron isotope fractionation during microbial reduction of iron: the importance of adsorption. Geology, 32(3): 205-208.

Ilina, S.M. et al., 2013. Extreme iron isotope fractionation between colloids and particles of boreal and temperate organic-rich waters. Geochimica et Cosmochimica Acta, 101: 96-111.

Kühnel, R., Roorda, H., Steensma, J., 1978. Distribution and partitioning of elements in nickeliferous laterites. Bull. BRGM, 2(3): 191-206.

Liermann, L.J. et al., 2011. Extent and isotopic composition of Fe and Mo release from two Pennsylvania shales in the presence of organic ligands and bacteria. Chemical Geology, 281(3-4): 167-180.

Liu, S.-A. et al., 2014. Copper and iron isotope fractionation during weathering and pedogenesis: insights from saprolite profiles. 
Maignien, R., 1966. REVIEW OF RESEARCH IN LATERITES.

Nahon, D., Colin, F., Tardy, Y., 1982b. Formation and distribution of Mg, Fe, Mn-smectites in the first stages of the lateritic weathering of forsterite and tephroite. Clay Minerals, 17(3): 339-348.

Nahon, D.B., Paquet, H., Delvigne, J., 1982a. Lateritic weathering of ultramafic rocks and the concentration of nickel in the western Ivory Coast. Economic Geology, 77(5): 1159-1175.

Nesbitt, H., Wilson, R., 1992. Recent chemical weathering of basalts. American Journal of Science, 292(10): 740-777.

Nesbitt, H.W., Markovics, G., 1980. Chemical processes affecting alkalis and alkaline earths during continental weathering. Geochimica et Cosmochimica Acta, 44(11): 1659-1666.

Patino, L.C., Velbel, M.A., Price, J.R., Wade, J.A., 2005. Element redistribution during weathering of volcanic rocks in sedentary landscapes. Geochimica et Cosmochimica Acta Supplement, 69: 683.

Poitrasson, F., 2006. On the iron isotope homogeneity level of the continental crust. Chemical Geology, 235(1): 195-200.

Poitrasson, F., Viers, J., Martin, F., Braun, J.-J., 2008. Limited iron isotope variations in recent lateritic soils from Nsimi, Cameroon: implications for the global Fe geochemical cycle. Chemical Geology, 253(1): 54-63.

Santos-Ynigo, L., 1964. Distribution of iron, alumina and silica in the Pujada Laterite of Mati, Davao province, Míndanao Island (Phillipines), 22 INTERNATIONAL GEOLOGICAL CONGRESS.

Skulan, J.L., Beard, B.L., Johnson, C.M., 2002. Kinetic and equilibrium Fe isotope fractionation between aqueous Fe (III) and hematite. Geochimica et Cosmochimica Acta, 66(17): 2995-3015.

Tardy, Y., 1997. Petrology of laterites and tropical soils. AA Balkema.

Thompson, A., Ruiz, J., Chadwick, O.A., Titus, M., Chorover, J., 2007. Rayleigh fractionation of iron isotopes during pedogenesis along a climate sequence of Hawaiian basalt. Chemical Geology, 238(1): 72-83.

Weyer, S., Schwieters, J., 2003. High precision Fe isotope measurements with high mass resolution MC-ICPMS. International Journal of Mass Spectrometry, 226(3): 355-368.

Wiederhold, J.G. et al., 2006. Iron isotope fractionation during proton-promoted, ligand-controlled, and reductive dissolution of goethite. Environmental science \& technology, 40(12): 3787-3793.

Wiederhold, J.G., Teutsch, N., Kraemer, S.M., Halliday, A.N., Kretzschmar, R., 2007a. Iron isotope fractionation in oxic soils by mineral weathering and podzolization. Geochimica et Cosmochimica Acta, 71(23): 5821-5833.

Wiederhold, J.G., Teutsch, N., Kraemer, S.M., Halliday, A.N., Kretzschmar, R., 2007b. Iron isotope fractionation during pedogenesis in redoximorphic soils. Soil Science Society of America Journal, 71(6): 1840-1850.

Yamaguchi, K.E. et al., 2007. Isotopic evidence for iron mobilization during Paleoproterozoic lateritization of the Hekpoort paleosol profile from Gaborone, Botswana. Earth and Planetary Science Letters, 256(3): 577-587.

Yesavage, T. et al., 2012. Fe cycling in the Shale Hills Critical Zone Observatory, Pennsylvania: An analysis of biogeochemical weathering and $\mathrm{Fe}$ isotope fractionation. Geochimica et Cosmochimica Acta, 99: 18-38.

Young, E.D., Galy, A., Nagahara, H., 2002. Kinetic and equilibrium mass-dependent isotope fractionation laws in nature and their geochemical and cosmochemical significance. Geochimica et Cosmochimica Acta, 66(6): 1095-1104.

Zeissink, H., 1969. The mineralogy and geochemistry of a nickeliferous laterite profile (Greenvale, Queensland, Australia). Mineralium Deposita, 4(2): 132-152.

Zhao, X., Zhang, H., Zhu, X., Tang, S., Yan, B., 2012. Iron isotope evidence for multistage melt-peridotite interactions in the lithospheric mantle of eastern China. Chemical geology, 292: 127-139. 


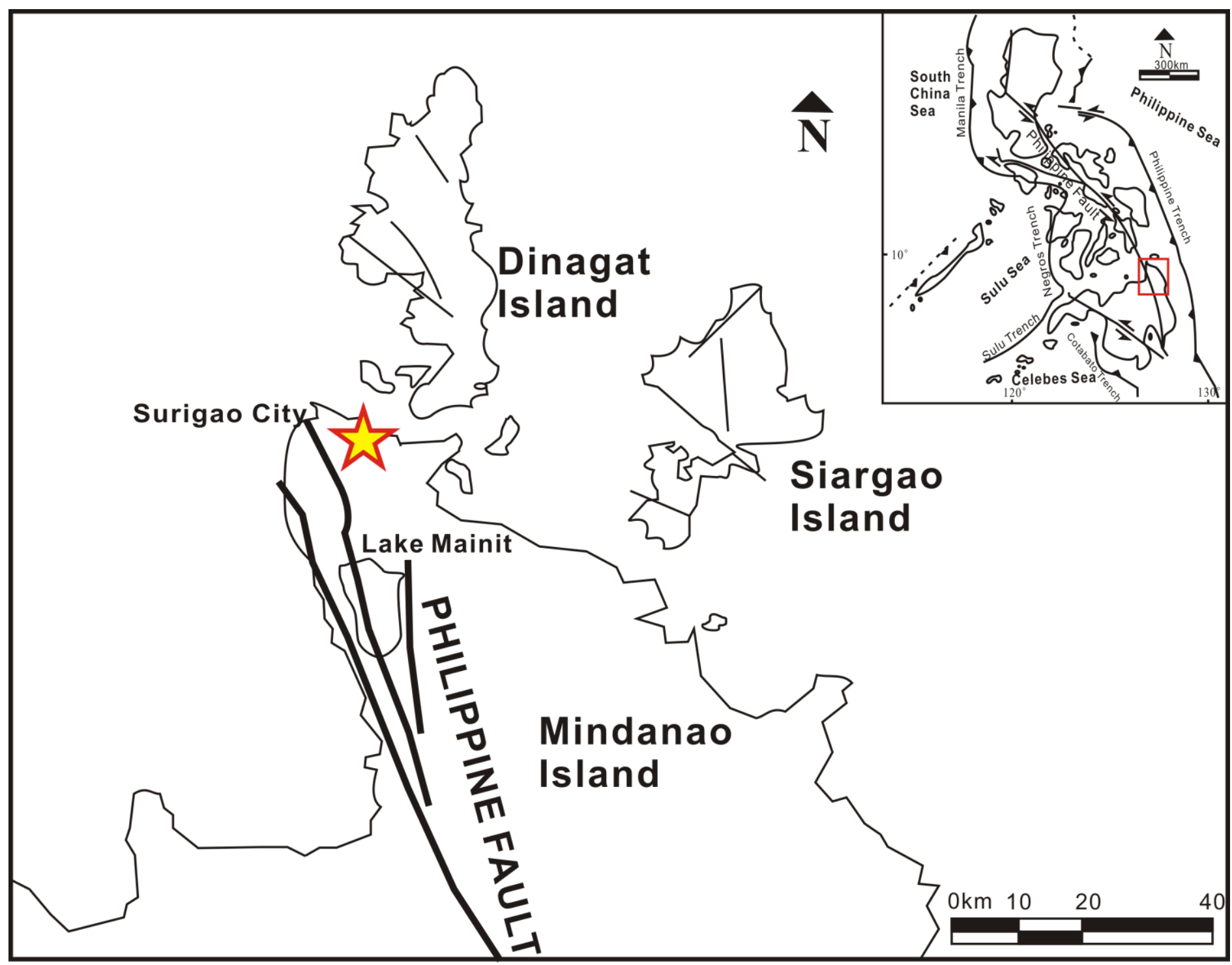

506

Fig. 1 


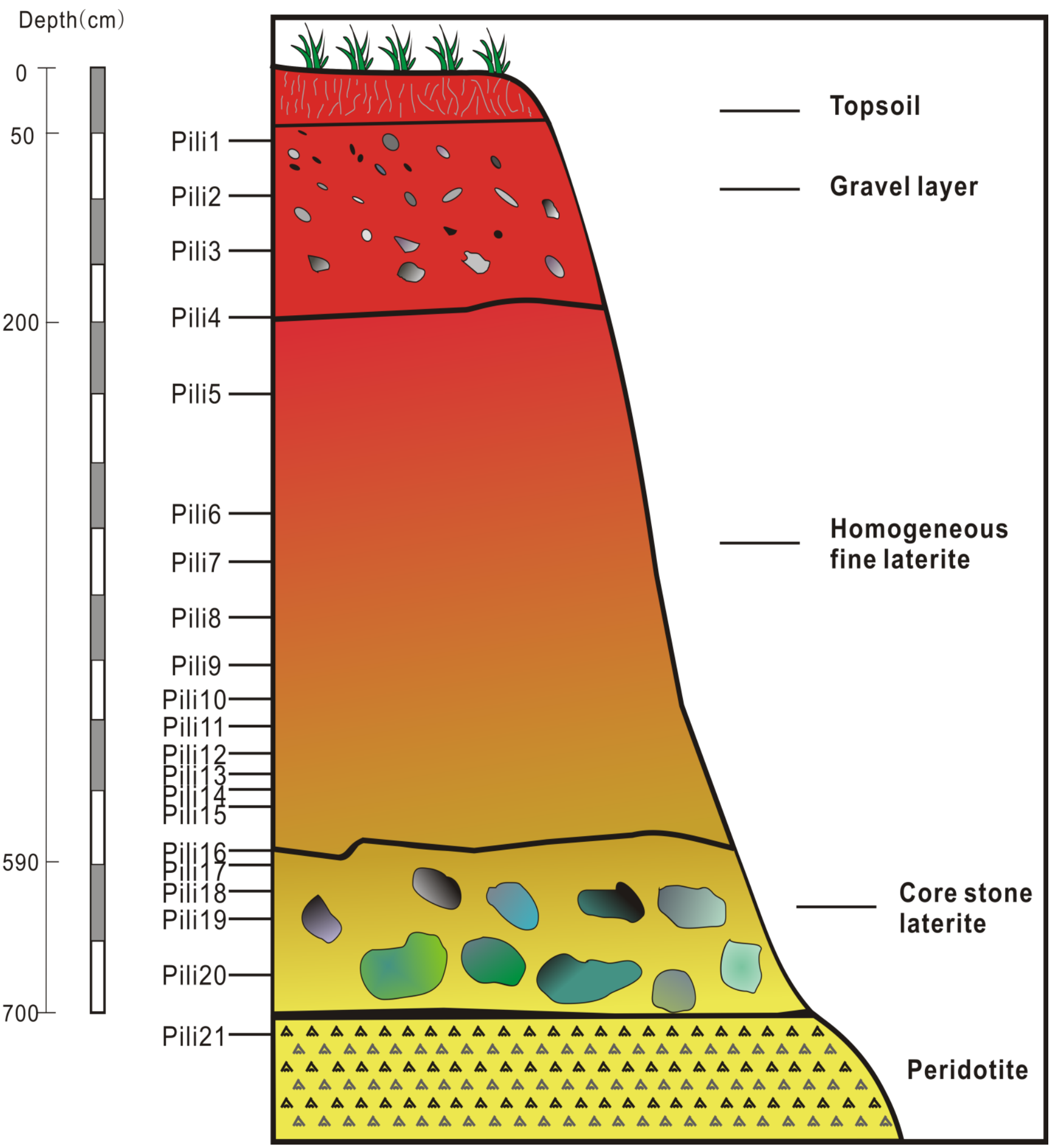

Fig. 2 


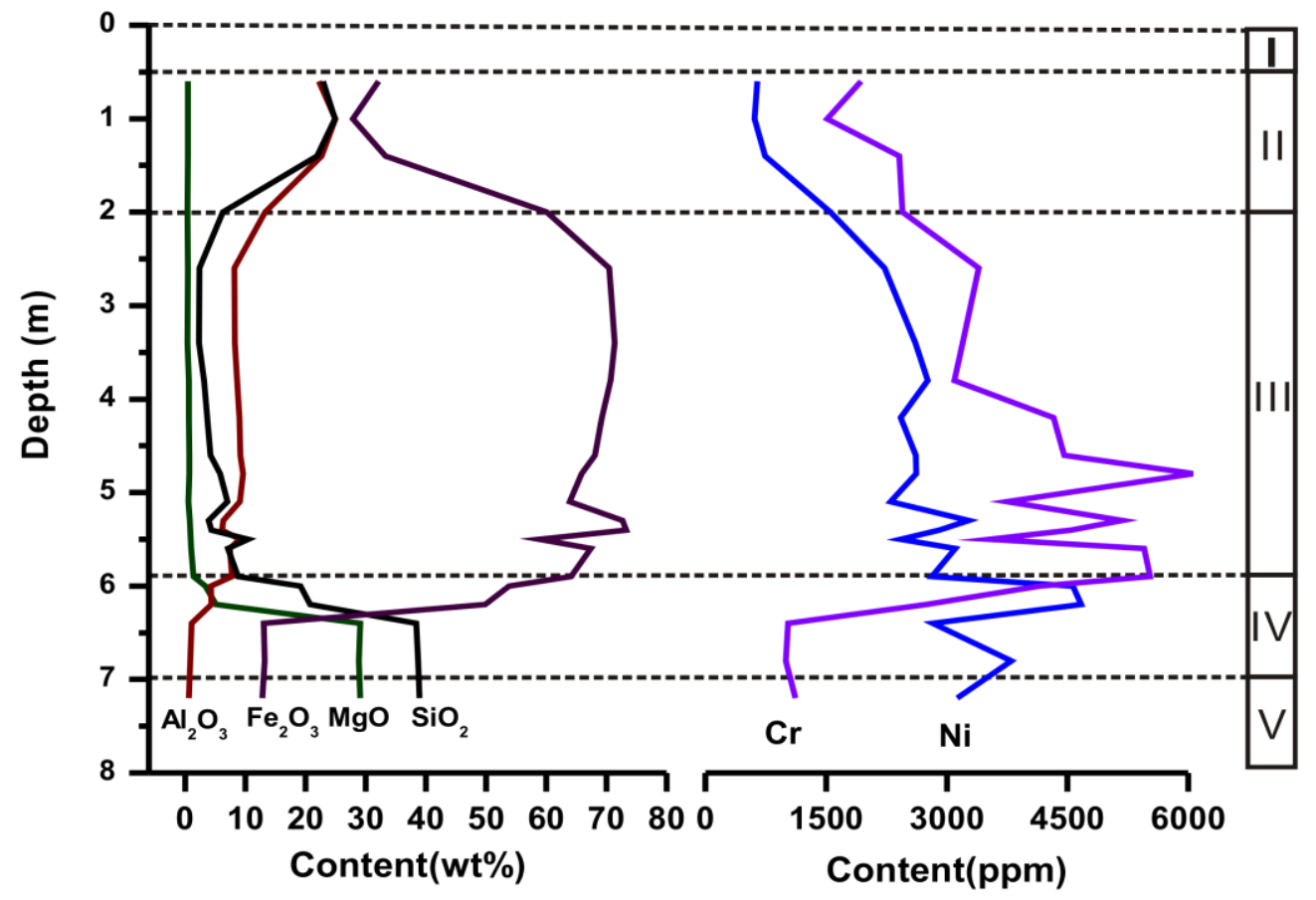

(a)

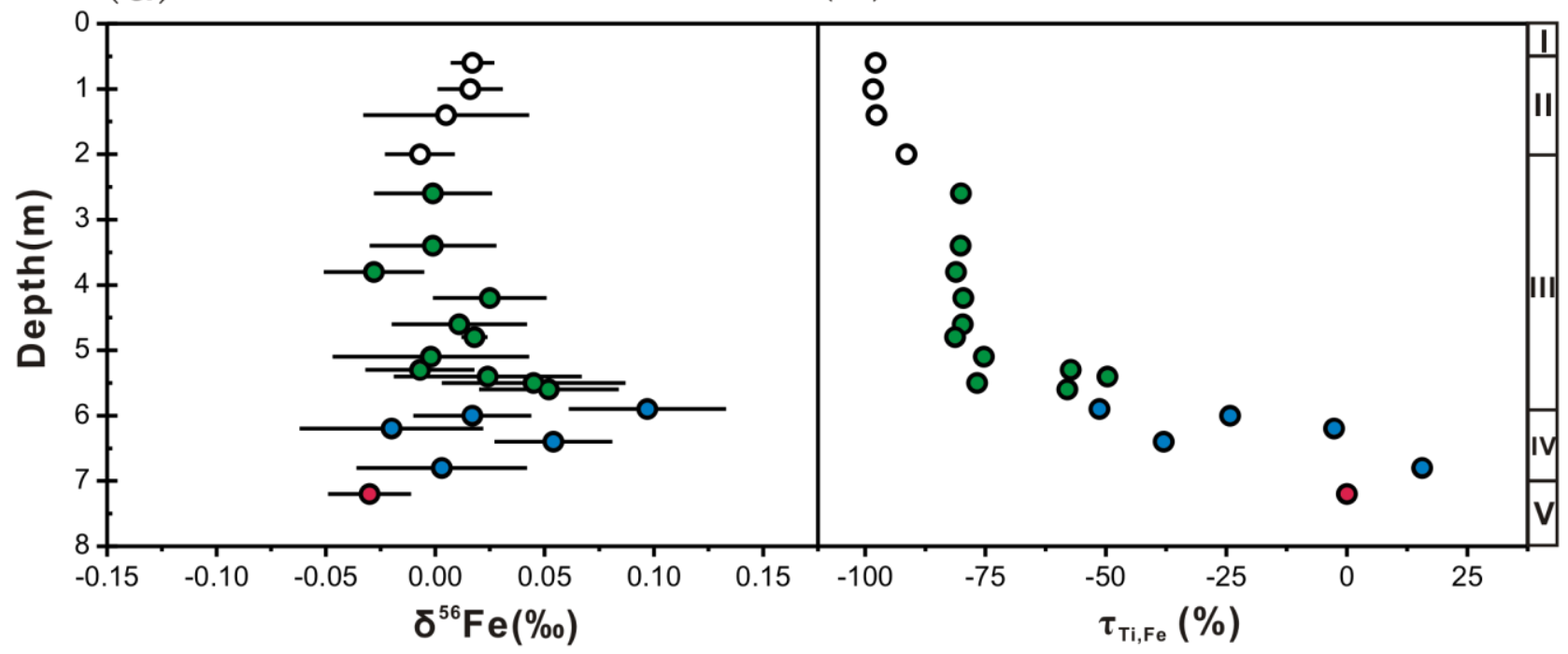

(b)

Fig. 4 


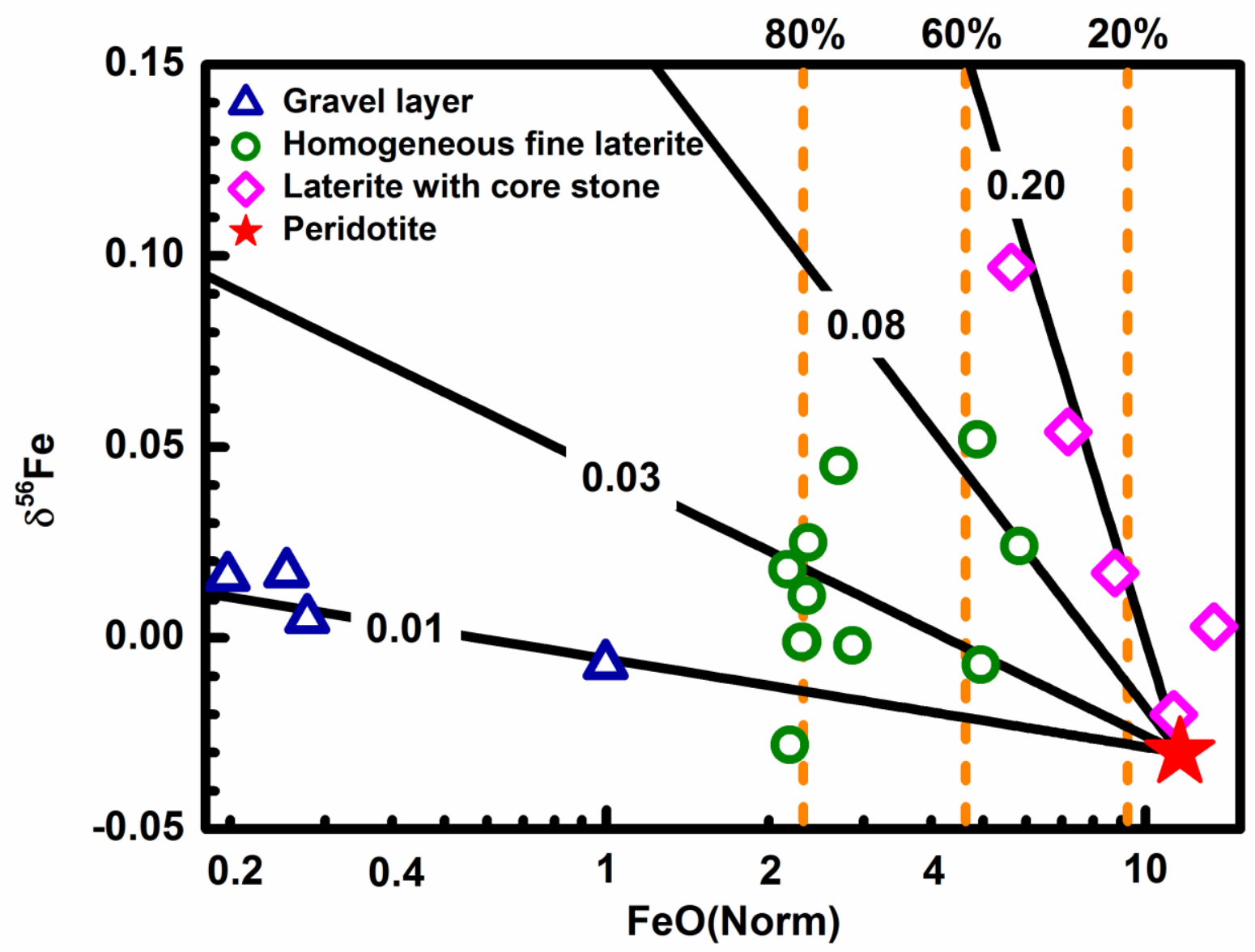

${ }_{521} \quad$ Fig. 5 


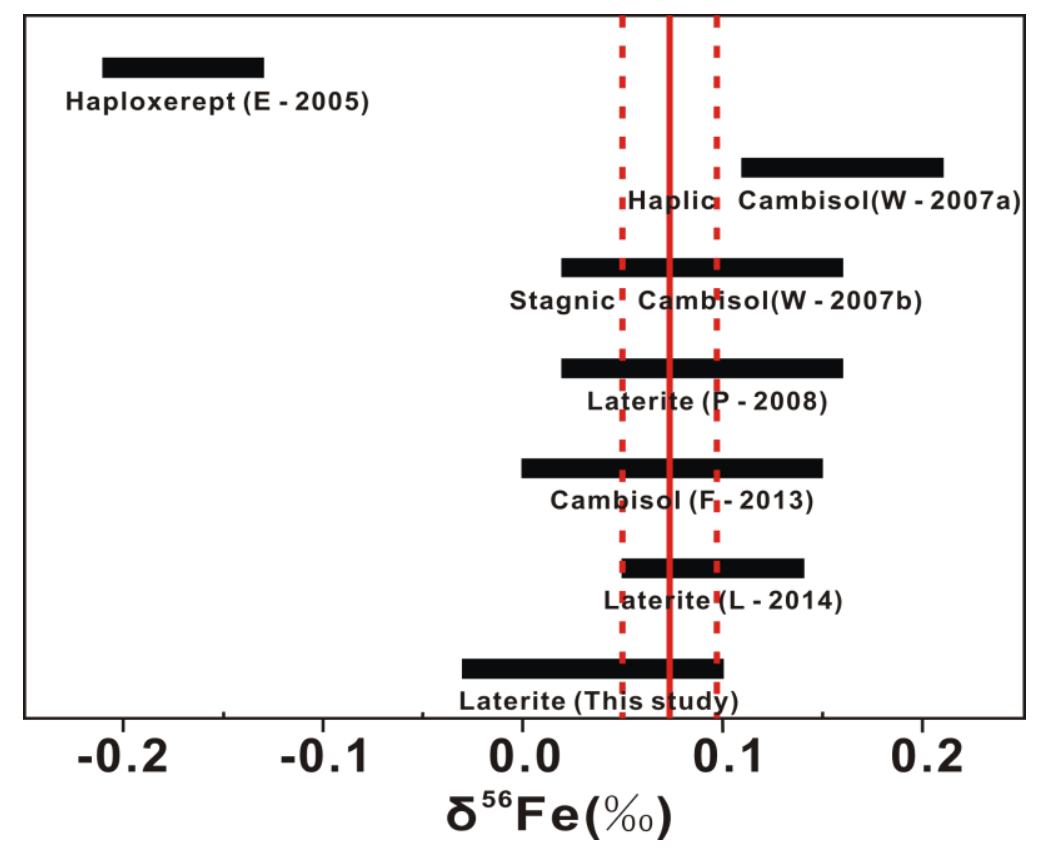

Fig. 6

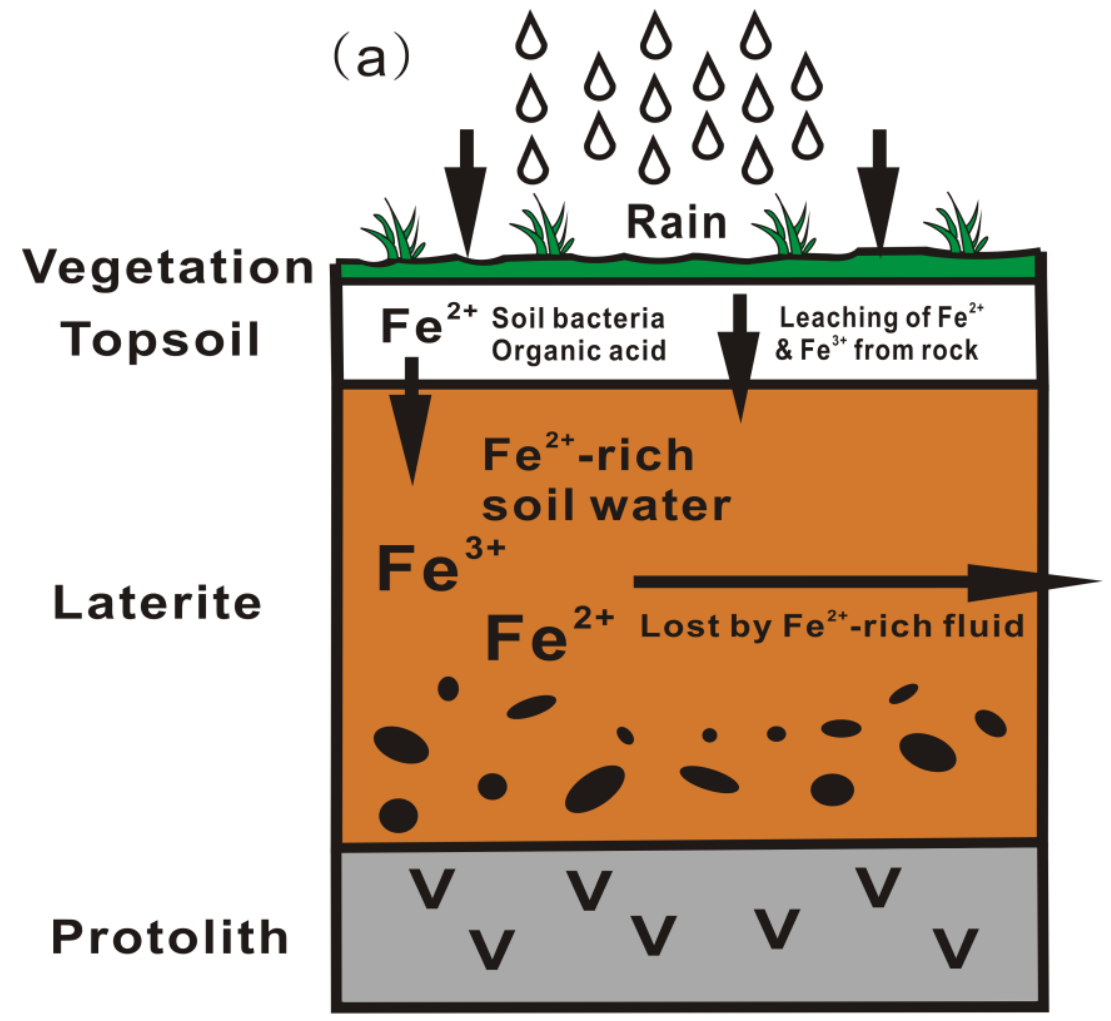

Reduced situation (b)

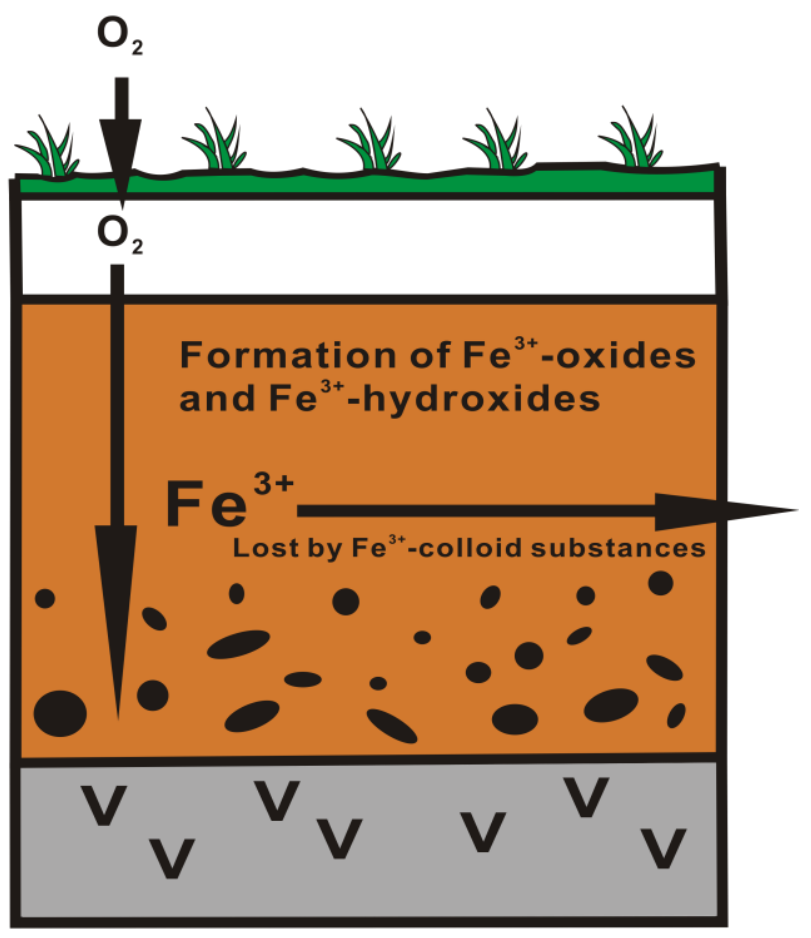

Oxidized situation

Fig. 7 